\title{
Deciphering epigenetic(s) role in modulating susceptibility to and severity of COVID-19 infection and/or outcome: a systematic rapid review
}

\author{
Sherihan G. AbdelHamid ${ }^{1}$ - Aya A. Refaat ${ }^{1}$ - Anthony M. Benjamin ${ }^{1} \cdot$ Laila A. Elmawardy $^{1} \cdot$ Lougine A. Elgendy $^{1}$. \\ Mark M. Manolly ${ }^{1} \cdot$ Nada Abd Elmaksoud $^{1} \cdot$ Nourhan Sherif $^{1} \cdot$ Nadia M. Hamdy $^{1}$ (I)
}

Received: 18 May 2021 / Accepted: 19 July 2021 / Published online: 12 August 2021

(C) The Author(s), under exclusive licence to Springer-Verlag GmbH Germany, part of Springer Nature 2021

\begin{abstract}
COVID-19 pandemic waves hitting worldwide result in drastic postinfection complications with interindividual variations, which raised the question for the cause of these observed variations. This urged to think "the impact of environment-affected genes"? In an attempt to unravel the impact of environment-affected genes, a systematic rapid review was conducted to study "the impact of host or viral epigenetic modulation on COVID-19 infection susceptibility and/or outcome." Electronic databases including Web of Science, SCOPUS, Cochrane Central Register of Controlled Trials, PubMed, and Google Scholar, and other databases were searched. The search strings included "COVID-19" OR "SARS-CoV-2" AND (Epigenetics'). Articles with randomized clinical trials (RCTs) and observational study designs, conducted on humans and available in the English language, were selected, with respect to "The interplay between the SARS-CoV-2 virus and Epigenetics" published from 2020 to February 2021 (but not limited to 2020, being expanded to 2015). Database search yielded 1330 articles; after screening, exclusion, and further filtrations, 51 articles were included. Susceptibility to COVID-19 infection is related to the viral-microRNAs (miRNAs) which alter virulence of the transmitted SARS-CoV-2 strains and impact host-miRNA-related innate immunity. Host-DNA methylation and/or chromatin remodeling may be implicated in severe cytokine storm that can ultimately results in fatal outcome.
\end{abstract}

Keywords Coronavirus $\cdot$ Epigenetics $\cdot$ MicroRNA $\cdot$ LncRNA $\cdot$ DNA methylation $\cdot$ Histonemodification $\cdot$ Chromatin remodeling

\section{Introduction}

\section{Problem}

The molecular mechanisms underlying severe acute respiratory syndrome COVID virus-2 (SARS-CoV-2) pathogenesis are not yet fully elucidated, with an urgent need to design an effective therapeutic regimen against the $\mathrm{CoV}-2$ pandemic that started November 2019 in China. Therefore, research is still going to unravel the pandemic molecular pathogenesis and find candidate effective therapeutic agents.

Responsible Editor: Lotfi Aleya

Nadia M. Hamdy

nadia_hamdy@pharma.asu.edu.eg

1 Biochemistry Department, Faculty of Pharmacy, Ain Shams University, 11566, Abassia, Cairo, Egypt

\section{Problem definition}

In an attempt to define and explain the interindividual difference in response to infection as well as variation in reaction to infection, several factors need to be defined. These factors may be either related to the virus or related to the host.

The scope of the current systematic rapid review (SRR) is to point out the epigenetic factors that may alter the viability and transmissibility of the CoV-2 strain (Samaddar et al. 2020); and to address "gene expression alteration" arising from either chromatin structure modulation or posttranscriptional and/or posttranslational activity by protein-RNA interaction (Schäfer and Baric 2017).

The epigenetic landscape tends to contribute, first, to variation in the host susceptibility to SARS-CoV-2 infection and, second, to the host-pathological features and/or severity of symptoms, where SARS-CoVs could epigenetically antagonize host-cell-signaling and sensing components, in order to facilitate viral replication and drive pathogenesis together with 
bypassing the host-induced innate immunity and/or the hostantiviral protection programs (Chlamydas et al. 2020). Besides, the host-pathogen interaction, witnessed in COVID-19-infected cases, results in striking variations in mortality rates across different geographical regions worldwide (Liu et al. 2020).

\section{Aim}

Summarizing the available knowledge regarding "the impact of epigenetics on the COVID-19 infection susceptibility, severity, and/or outcome." This, secondly, would hold a promise to personalized/precision medicine (PM) for better, hopefully successful, future treatment options, via proper identification and understanding of the host epigenetics.

\section{Objectives}

The current SRR was conducted to answer the following questions: (1) What are the host-epigenetic modifications that are associated with susceptibility and severity of COVID-19 infection? And how does SARS-CoV-2-epigenome influence host-infection susceptibility? (2) What is the role of epigenetics in modulating SARS-CoV-2 infection and/or its mutated forms in humans? (3) What is the value/influence of such epigenetic modification(s) on postinfection prognosis, complications, and/or outcome?

\section{Methods}

\section{Design}

\section{Type of the review}

Diagnostic, epidemiologic, prognostic.

PROSPERO registration \#: CRD42021229133, was done on 8 January 2021.

https://www.crd.york.ac.uk/prospero/display_record.php? $\mathrm{ID}=\mathrm{CRD} 42021229133$

\section{Searched electronic databases}

The searched electronic databases were PubMed, ScienceDirect, Google Scholar, SCOPUS, Embase, CINAHL, SciELO, BVS, CAPES, LILACS, EBSCO, EMBASE, the Cochrane Library, and the grey literature search including the National Human Genome Research Institute (https://www.genome.gov/), WHO databases, and CDC. All records retrieved from database searches were downloaded locally and managed using the Mendeley X86 software facilities.

\section{Study selection}

Performed by two investigators independently with any disagreements being resolved by either the senior investigator or the chief investigator. Titles and abstracts selected for eligibility by two investigators from the studies retrieved during the searches and those identified meeting the inclusion criteria were chosen for use in the review by two authors and rechecked by another two authors, and then all investigators agreed for them. Any duplicates were removed using Mendeley X86 (Mendeley Desktop 1.19.8, by Mendeley Ltd.). Selected data was summarized using an Excel spreadsheet, full-text articles or reports which do not meet the inclusion criteria were excluded, and the reason(s) for exclusion are provided in the PRISMA Flowchart (Fig. 1). Moreover, the full texts of potentially eligible studies (51) were retrieved and evaluated independently for eligibility by both the senior and the chief investigators.

Data extracted included specific details about the condition, context, population, and study methods of significance to the review question(s) and specific objectives. PRISMA guidelines (Liberati et al. 2009) for systematic review presentation were followed.

Data extraction/synthesis is summarized in Tables 1, 2, 3, and 4 which include all epigenetics that were found to be associated with COVID-19, with no restrictions regarding country, race, gender, or age, and were classified into different epigenetics and the corresponding significance in relation to infection.

\section{Results}

Figure 1 outlines the PRISMA flowchart for the selection process, where a total of 2332 articles were found after searching for different databases. Duplicates (1002) found by Mendeley X86 were excluded. After title and abstract screening of the 1330 papers included, 1278 articles were found irrelevant (reasons are stated in the chart). Total eligible articles are 51.

Tables 1, 2, 3, and 4 summarizes the epigenetics landscape in SARA-CoV-2 infection, describing the association of various epigenetic factor(s) with different aspects of SARS-CoV2 infection, namely, virus entrance into the host cell, viral replication, infection severity, postinfection complications as either cardiovascular (CV), pulmonary complications, or cytokine storm (CS) and more.

Figure 2 entitles the CoV-2 host-immune escaping mechanism(s) resulting in silent viral infection and fatal CS.

Figure 3 illustrates the CoV-2 infection-outcome regulatory triangle system consisting of the host, virus, and epigenetic target(s). 
Fig. 1 PRISMA Flowchart

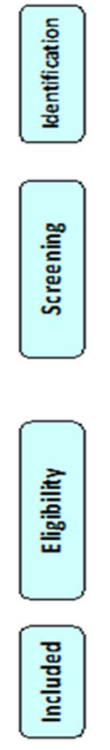

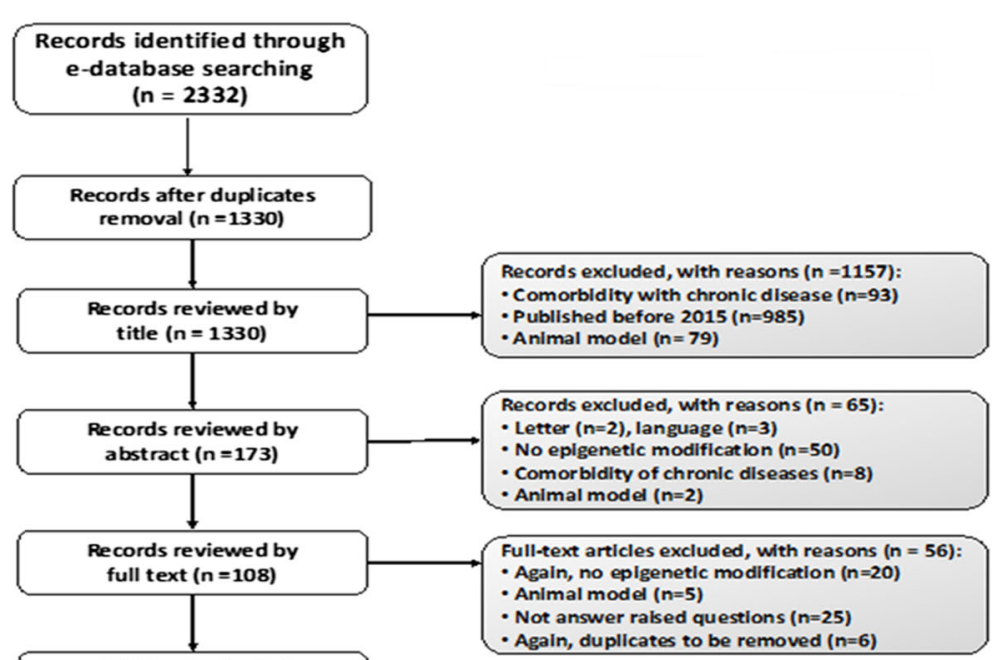

Articles included

in the SRR $(n=52)$
Figure 4 collectively highlights the epigenetic modulation(s) to address "gene expression alteration" as molecular mechanisms of SARS-CoV-2 pathogenesis.

\section{Discussion}

\section{Epigenetic modifications}

\section{Small nonprotein-coding RNAs (ncRNAs)}

ncRNAs comprise RNA molecules that do not encode a protein but regulate gene expression at multiple levels, including RNA splicing, editing, chromatin structure, and transcription (Canatan 2020). The ncRNA landscape of host cells could affect their vulnerability to viral infection and have a pivotal role in the cellular innate immune response against viruses (Henzinger et al. 2020).

\section{MicroRNAs (miRNAs)}

miRNAs are 19-23 nucleotides RNAs that regulate posttranscriptional silencing via targeting the messenger RNAs (mRNAs) 3' untranslated region (3'UTR) (Canatan 2020). miRNAs regulate the expression of genes involved in various cellular processes and have, recently, emerged as critical modulators of viral infections (Henzinger et al. 2020; Meng et al. 2020).

In addition, viral-miRNAs can function as posttranscriptional gene regulators to both the host and viral genes (Pradhan et al. 2020). Understanding these processes holds a promise for the use of miRNAs as diagnostic or prognostic markers. Studying epigenetics to pave the road for finding the potential viral-miRNA-based treatments targets (epi-drugs) for successful personalized SARS-CoV-2 treatment (AbuIzneid et al. 2020) is the future for implementing sustainable development goals (SDGs Vision 2030) and PM for good health (SDG \#3) with minimal medications use, minimal side effects, and better environmental saving.

Role of miRNAs towards viral invasion, viral replication, pathogenies, and cellular response-to-viral infection

This includes two axes either the host or the viral epigenetics.

\section{Host miRNAs}

SARS-CoV-2 utilizes its spike (S) protein to mediate cell invasion. Human miRNAs, namely hsa-miR-8066, hsa-miR5197-3p, and hsa-miR-3934-3p, were found to regulate the viral S protein synthesis (Abedi et al. 2020), which is also targeted by hsa-miR-98-5p in bronchoalveolar stem cells (Beidas and Chehadeh 2018). Moreover, host miRNAs regulate the expression of the most crucial proteins involved in SARS-CoV-2 cell invasion including human angiotensinconverting enzyme2 (ACE2), type II transmembrane serine protease 2 (TMPRSS2), and possibly a disintegrin and metalloproteinase domain 17 (ADAM17) and furin (Pontecorvi et al. 2020). ACE2 enables SARS-CoV-2 entry into host cells, being the receptor for the viral $\mathrm{S}$ protein cells attachment (Crimi et al. 2020; Shang et al. 2020). Other co-receptors required to complete the invasion process include TMPRSS2, which catalyzes cleavage and activation of the S protein. However, furin and ADAM17 are involved in membrane fusion (Shang et al. 2020). It was found that miR-421 and miR-143 decrease the expression of ACE2 (Ragia and 
Table 1 Epigenetic noncoding RNA landscape in SARS-CoV-2 infection

\begin{tabular}{|c|c|c|c|}
\hline \multicolumn{2}{|c|}{ Epigenetic factor } & \multirow{2}{*}{$\begin{array}{l}\text { Significance } \\
\text { Affect ACE2/TMPRSS2 expression }\end{array}$} & \multirow{2}{*}{$\begin{array}{l}\text { References } \\
\begin{array}{c}\text { Henzinger et al. } \\
(2020)\end{array}\end{array}$} \\
\hline $\begin{array}{l}\text { Noncoding } \\
\text { RNAs }\end{array}$ & $\begin{array}{l}\text { hsa-let-7e/hsa-mir-125a and } \\
\text { hsa-mir-141/hsa-miR-200 }\end{array}$ & & \\
\hline & $\begin{array}{l}\text { hsa-let-7a, hsa-miR101, hsa-miR125a-5p, } \\
\text { hsa-miR126, 222, 23b, 378, 380-5 and hsamiR-98 }\end{array}$ & $\begin{array}{l}\text { Diagnostic biomarkers that may determine the occurrence and } \\
\text { possible severity of the infection }\end{array}$ & $\begin{array}{l}\text { Abu-Izneid et al. } \\
\text { (2020) }\end{array}$ \\
\hline & hsa-miR-27b & $\begin{array}{l}\text { Hypothesized to have a specific role in defense against } \\
\text { SARS-CoV-2 in the Indian population }\end{array}$ & \multirow[t]{11}{*}{$\begin{array}{l}\text { Abedi et al. } \\
\text { (2020) }\end{array}$} \\
\hline & $\begin{array}{l}\text { miR-376a-3p, miR-10a-5p, miR-548av-5p and } \\
\text { miR-99b-5p }\end{array}$ & Host miRNA sponges & \\
\hline & miRNA MD3-3P & Target and inhibit the $p 53$ gene & \\
\hline & $\begin{array}{l}\text { miR15b-5p, miR15a-5p, miR197-5p, miR548c-5p, } \\
\text { miR548d-5p, miR409-3p, miR30b-5p } \\
\text { miR505-3p }\end{array}$ & Involved in blocking viral replication & \\
\hline & $\begin{array}{l}\text { hsa-miR-8066, hsa-miR-5197-3p, and } \\
\text { hsa-miR-3934-3p }\end{array}$ & Regulate the synthesis of the viral Spike $S$ protein & \\
\hline & hsa-miR-1468-5p & Mediate cardiac tissue damage & \\
\hline & miRNA-320a & Downregulates GLUT1 (SLC2A1 gene) & \\
\hline & $\begin{array}{l}\text { miRNA-1-5p, miRNA-2-5p, miRNA-3-5p, } \\
\text { miRNA-4-5p, miRNA-5-5p, and miRNA-6-5p }\end{array}$ & $\begin{array}{l}\text { Involved directly/indirectly in the immune response upregula- } \\
\text { tion and the pathway of chemokine signaling }\end{array}$ & \\
\hline & miRNA $66-3 p$ & Targets TNF-alpha & \\
\hline & miRNA147-3p & $\begin{array}{l}\text { Increased TMPRSS } 2 \text { gene expression in the gut and may be } \\
\text { associated with the gastrointestinal symptoms of COVID-19 }\end{array}$ & \\
\hline & hsa-miR-8066 and hsa-miR-5197-3p & Involved with mucin-type-O-glycan synthesis & \\
\hline & hsa- miR-98-5p & Targets viral S protein in bronchoalveolar stem cells & $\begin{array}{l}\text { Beidas and } \\
\text { Chehadeh } \\
\text { (2018) }\end{array}$ \\
\hline & $\begin{array}{l}\text { miR-145 let-7, miR-145, and miR-222 } \\
\text { miR-20b, miR-19a, miR-19b, and miR-106a }\end{array}$ & $\begin{array}{l}\text { Regulators of ADAM- } 17 \text { expression } \\
\text { Reregulate Furin activity }\end{array}$ & $\begin{array}{l}\text { Pontecorvi et al. } \\
\text { (2020) }\end{array}$ \\
\hline & miR-421 and miR-143 & Decrease the expression of ACE2 & $\begin{array}{l}\text { Ragia and } \\
\text { Manolopoulos } \\
\text { (2020) }\end{array}$ \\
\hline & $\begin{array}{l}\text { hsa-mir-9-5p } \\
\text { hsa-mir-27b-3p }\end{array}$ & $\begin{array}{l}\text { Targets } 3 \text { ' UTR of ACE2 } \\
\text { Plays a regulatory role in ACE2 signaling }\end{array}$ & $\begin{array}{l}\text { Khan and Islam } \\
\text { (2020) }\end{array}$ \\
\hline & $\begin{array}{l}\text { hsa-miR-7849-3p, hsa-miR-7849-3p, } \\
\text { hsa-miR-7849-3p, and hsa-miR-7849-3p }\end{array}$ & Regulate TMPRSS2 gene expression & $\begin{array}{l}\text { Zarubin et al. } \\
\quad(2020)\end{array}$ \\
\hline & $\begin{array}{l}\text { hsa-miR-17-5p, hsa-miR-20b-5p, and } \\
\text { hsa-miR-323a-5p }\end{array}$ & $\begin{array}{l}\text { Antiviral activity; targeting pathways involved in suppression } \\
\text { of viral entry, viral replication, and translation mechanisms }\end{array}$ & Khan et al. (2020) \\
\hline & miRNA $197-5 p$ & Implicated in cardiovascular complications post $\mathrm{CoV}-2$ & \multirow{3}{*}{$\begin{array}{l}\text { de Sanctis et al. } \\
\quad(2020)\end{array}$} \\
\hline & miRNA-8066 & Induce pro-inflammatory cytokines synthesis & \\
\hline & $\begin{array}{l}\text { miRNA }(8066,5197,3611,3934-3 p, 1307-3 p, 3691- \\
\quad 3 p, 1468-5 p)\end{array}$ & Modulate cell response and facilitate SARS-CoV2 infection & \\
\hline & $\begin{array}{l}\text { miR-574-5p, miR-214, miR-17, miR-98, miR-223, } \\
\text { miR-148a }\end{array}$ & Mediating immunity & $\begin{array}{l}\text { Hosseini Rad and } \\
\text { McLellan- } \\
\text { (2020) }\end{array}$ \\
\hline & $\begin{array}{l}\text { hsa-let-7a, hsa-miR101, hsa-miR125a-5p, } \\
\text { hsa-miR126, hsa-miR222, hsa-miR23b, } \\
\text { hsa-miR378, hsa-miR380-5, and hsa-miR98 }\end{array}$ & $\begin{array}{l}\text { Potentially target SARS-CoV-2, where hsa-miR-27b is hy- } \\
\text { pothesized to have a specific defensive role against } \\
\text { SARS-CoV-2 in the Indian population }\end{array}$ & $\begin{array}{l}\text { Samaddar et al. } \\
\text { (2020), Sardar } \\
\text { et al. (2020) }\end{array}$ \\
\hline & $\begin{array}{l}\text { miR-320a, miR-3188, miR-3661, miR-217, } \\
\text { miR-421, miR-429, and miR-421 }\end{array}$ & $\begin{array}{l}\text { Involved in the deregulation of pathways involved in the acute } \\
\text { lung injury post-CoV-2 infection }\end{array}$ & $\begin{array}{l}\text { Islam and Khan } \\
\text { (2020) }\end{array}$ \\
\hline
\end{tabular}

Manolopoulos 2020). hsa-miR-9-5p targets 3' UTR of ACE2, and hsa-miR-27b-3p plays a regulatory role during ACE2 signaling (Khan and Islam 2020). The miRNAs hsa-let-7e/ hsa-mir-125a and hsa-mir-141/hsa-miR-200 can affect ACE2/TMPRSS2 expression, and their Jardin transcription was found to be repressed by lysine-specific demethylase 5B and Jumonji/ARID domain-containing protein $1 \mathrm{~B}$ (JARID1B) (Abedi et al. 2020). miR-20b, miR-19a, miR$19 \mathrm{~b}$, and miR-106a can posttranscriptionally regulate furin expression (Pontecorvi et al. 2020). Moreover, TMPRSS2 
Table 2 Epigenetic DNA methylation landscape in SARS-CoV-2 infection

\begin{tabular}{|c|c|c|c|}
\hline \multicolumn{2}{|c|}{ Epigenetic factor } & \multirow{2}{*}{$\begin{array}{l}\text { Significance } \\
\begin{array}{l}\text { Reduces S protein } \\
\text { priming }\end{array}\end{array}$} & \multirow{2}{*}{$\begin{array}{c}\text { References } \\
\text { Henzinger } \\
\text { et al. } \\
(2020)\end{array}$} \\
\hline $\begin{array}{l}\text { DNA } \\
\text { methyla- } \\
\text { tion }\end{array}$ & TMPRSS2 methylation & & \\
\hline & $\begin{array}{l}\text { Hypomethylation at the } \\
\text { CpG site }\end{array}$ & $\begin{array}{l}\text { Increased } \\
\quad \text { expression of } \\
\text { ACE2 gene }\end{array}$ & $\begin{array}{l}\text { Franzen } \\
\text { et al. } \\
\quad(2020)\end{array}$ \\
\hline & $\begin{array}{l}\text { Methylation of adenine } \\
\text { of mRNA molecules in } \\
\text { position } 6 \\
\text { (N6-methyladenosine, } \\
\text { m6A) }\end{array}$ & $\begin{array}{l}\text { Alters mRNA } \\
\text { stability of } \\
\text { cellular and viral } \\
\text { transcripts, } \\
\text { affecting their } \\
\text { translation } \\
\text { efficiency and } \\
\text { RNA-protein } \\
\text { interaction }\end{array}$ & $\begin{array}{l}\text { Choudhary } \\
\text { et al. } \\
\text { (2020) }\end{array}$ \\
\hline & $\begin{array}{l}\text { Demethylation of } \\
\text { IFN-regulated genes, } \\
\mathrm{NF}_{-\mathrm{k}} \mathrm{B} \text {, and main cy- } \\
\text { tokine genes }\end{array}$ & $\begin{array}{l}\text { Enhances the } \\
\text { expression of } \\
\text { pro-inflammatory } \\
\text { cytokines and } \\
\text { chemokines, } \\
\text { increasing } \\
\text { cytokine storms } \\
\text { incidence }\end{array}$ & $\begin{array}{l}\text { El Baba } \\
\text { and } \\
\text { Herbein } \\
(2020)\end{array}$ \\
\hline
\end{tabular}

Table 4 Epigenetic chromatin remodeling landscape in SARS-CoV-2 infection

\begin{tabular}{|c|c|c|c|}
\hline \multicolumn{2}{|c|}{ Epigenetic factor } & \multirow{2}{*}{$\begin{array}{l}\text { Significance } \\
\text { Alters the activity of } \\
\text { gene regulatory } \\
\text { regions in the } \\
\text { lung (PIR, CA5B, } \\
\text { and VSP13C) }\end{array}$} & \multirow{2}{*}{$\begin{array}{c}\text { References } \\
\text { Fadason } \\
\text { et al. } \\
(2020)\end{array}$} \\
\hline $\begin{array}{c}\text { Chromatin } \\
\text { remod- } \\
\text { eling }\end{array}$ & $\begin{array}{l}\text { SARS-COV-2-induced } \\
\text { repression of ACE2 } \\
\text { via chromatin } \\
\text { remodeling }\end{array}$ & & \\
\hline & $\begin{array}{l}\text { Chromatin remodeling } \\
\text { in CD14+ monocytes }\end{array}$ & $\begin{array}{l}\text { Affect the severity } \\
\text { of symptoms and } \\
\text { provide potential } \\
\text { prognostic } \\
\text { markers for } \\
\text { COVID-19 sub- } \\
\text { jects }\end{array}$ & $\begin{array}{l}\text { Giroux } \\
\quad \text { et al. } \\
(2020)\end{array}$ \\
\hline
\end{tabular}

gene expression was shown to be regulated by hsa-miR-78493p, hsa-miR-7849-3p, hsa-miR-7849-3p, and hsa-miR-7849$3 p$ (Zarubin et al. 2020). miR-145 let-7, miR-145, and miR222 are implicated as regulators of ADAM-17 expression (Pontecorvi et al. 2020). On the other hand, miR-145 was found to be upregulated by vitamin $\mathrm{D}$, which might explain COVID-19 severe progression in patients with vitamin D deficiency (Daneshkhah et al. 2020), as summarized in Table 1.

In addition to cell invasion, miRNA-mediated interactions between the host and the SARS-CoV-2 virus have several implications in terms of disease complexity. During viral infection, host-cell miRNAs bind to viral mRNAs resulting in
Table 3 Epigenetic histone modification landscape in SARSCoV-2 infection

\begin{tabular}{|c|c|c|c|}
\hline \multicolumn{2}{|c|}{ Epigenetic factor } & \multirow{2}{*}{$\begin{array}{l}\text { Significance } \\
\text { Affects ACE2 expression }\end{array}$} & \multirow{2}{*}{$\begin{array}{l}\text { References } \\
\text { Chlamydas } \\
\text { et al. (2020) }\end{array}$} \\
\hline $\begin{array}{l}\text { Histone } \\
\text { modifica- } \\
\text { tions }\end{array}$ & $\begin{array}{l}\text { Methylation of } \\
\text { H3K4 at the } A C E 2 \\
\text { gene promoter }\end{array}$ & & \\
\hline & $\begin{array}{l}\text { High level of } \\
\text { repressive histone } \\
\text { marks }\end{array}$ & $\begin{array}{l}\text { Reduction of IL-12 and IL- } 1 \beta \text {, contributing to } \\
\text { CoV-2 severity }\end{array}$ & \\
\hline & $\mathrm{H} 3 \mathrm{~K} 4 \mathrm{me} 3$ & $\begin{array}{l}\text { Regulates TLRs involved in the innate immune } \\
\text { system }\end{array}$ & \multirow{2}{*}{$\begin{array}{l}\text { El Baba and } \\
\text { Herbein } \\
(2020)\end{array}$} \\
\hline & $\begin{array}{l}\mathrm{H} 3 \mathrm{~K} 9 \mathrm{ac}, \mathrm{H} 3 \mathrm{~K} 36 \mathrm{ac} \\
\text { and } \mathrm{H} 4 \mathrm{~K} 5 \mathrm{ac}\end{array}$ & $\begin{array}{l}\text { Suppression of IL- } 8 \text { and TNF-alpha levels in re- } \\
\text { sponse to CoV }\end{array}$ & \\
\hline & $\begin{array}{l}\mathrm{H} 3 \mathrm{~K} 4 \mathrm{me} 1, \mathrm{H} 3 \mathrm{~K} 4 \mathrm{me} 3 \\
\mathrm{H} 3 \mathrm{~K} 27 \mathrm{Ac} \text { in the } \\
\text { ACE2 gene } \\
\text { NAD-dependent } \\
\text { histone deacetylase } \\
\text { sirtuin } 1\end{array}$ & Increased ACE2 expression & $\begin{array}{l}\text { Pinto et al. } \\
\quad(2020)\end{array}$ \\
\hline & $\begin{array}{l}\text { Acetylation and } \\
\text { hypermethylation of } \\
\text { histone marks }\end{array}$ & $\begin{array}{l}\text { Upregulation of pro-inflammatory cytokines } \\
\text { (IL-1 } \beta \text {, IL-6, IL-12, TNF-5-007) and } \\
\text { chemokines (CCL2, CCL3, CCL5, CXCL8, } \\
\text { CXCL9, CXCL10) contributing to cytokine } \\
\text { storms }\end{array}$ & $\begin{array}{r}\text { Ovsyannikova } \\
\text { et al. (2020) }\end{array}$ \\
\hline & H3 modifications & $\begin{array}{l}\text { NET in organ damage and mortality in } \\
\text { COVID-19 patients }\end{array}$ & $\begin{array}{l}\text { McCracken } \\
\text { et al. }(2020)\end{array}$ \\
\hline & $\begin{array}{l}\text { G9a, a histone } \\
\text { methyltransferase }\end{array}$ & $\begin{array}{l}\text { Increased inflammation and T-cell function im- } \\
\text { pairment or lymphopenia }\end{array}$ & $\begin{array}{l}\text { Wang et al. } \\
\quad(2020)\end{array}$ \\
\hline & H3K27 acetylation & Expression of inflammation-associated genes & Li et al. (2020) \\
\hline
\end{tabular}




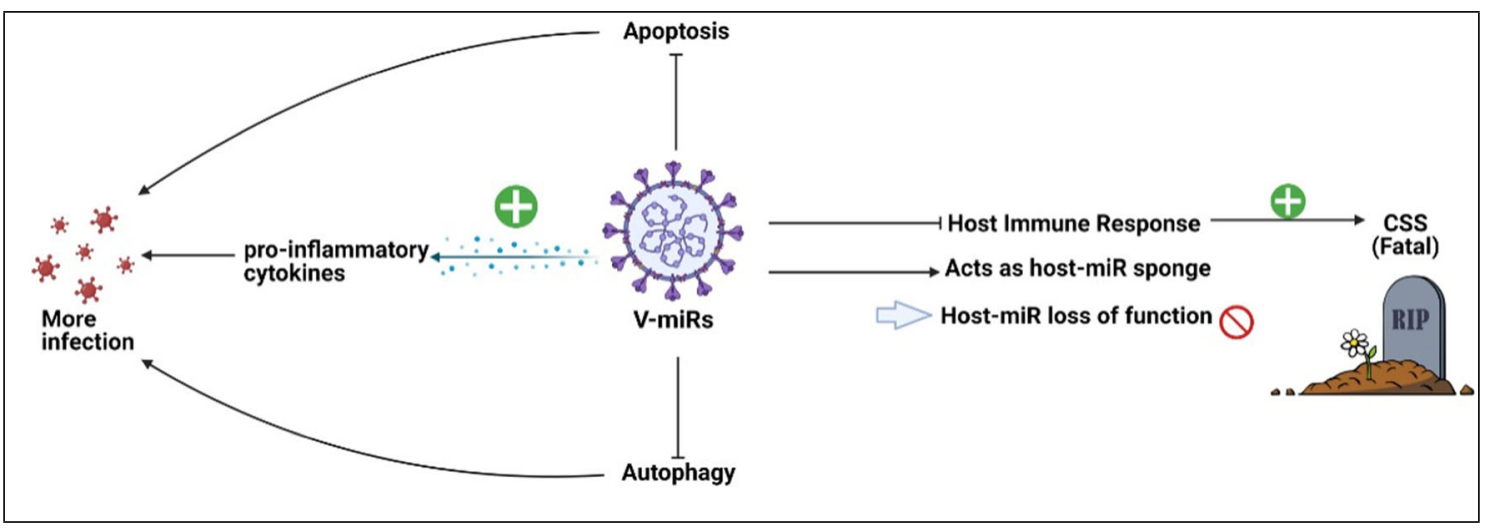

Fig. 2 SARS-CoV-2 host-immune-escaping mechanism(s) without symptoms of COVID-19 infection

either inhibition of viral genome translation and, hence, inhibition of viral replication or viral-RNA stabilization rendering the virus resistant to the host immune response (Abu-Izneid et al. 2020). In silico assessment has identified 873 miRNAs that could target SAR-CoV-2 genes (Srivastava et al. 2020). Those identified 873 miRNAs could be associated with the modulation of the innate and adaptive host immune response to viral infection (Abu-Izneid et al. 2020), an impact that may be either direct or indirect via influencing the interferon (IFN)alpha/beta signaling.

On the one hand, several host miRNAs nowadays are reported to exhibit experimentally evidenced antiviral activities, as hsa-miR-17-5p, hsa-miR-20b-5p, and hsa-miR-323a-5p, via suppression of the virus entry to cells (such as plateletderived growth factor receptor-like, PI3K-Akt, and cadherin signaling) or suppression of viral replication and suppression of viral proteins translation mechanisms (such as p38, mitogen-activated protein kinase (MAPK), and focal adhesion kinase (FAK) signaling) (Khan et al. 2020).
Bioinformatic assessments revealed host miRs (15b-5p, 15a-5p, 197-5p, 548c-5p, 548d-5p, 409-3p, 30b-5p, 505-3p) that may be involved in blocking viral replication (de Sanctis et al. 2020). Some miRNAs are hypothesized to fight SARSCoV-2 efficiently by triggering a defensive response and reducing host cell apoptosis (Abedi et al. 2020). Hosseini et al. identified seven miRNA targets in the SARS-CoV-2 genome that mediates immunity (miR-574-5p, miR-214, miR-17, miR-98, miR-223, and miR-148a) (Hosseini Rad and McLellan 2020). Sardar et al. found 51 miRNAs interacting with 77 transcription factors that are involved in the hostantiviral activity modulation (Sardar et al. 2020).

On the other hand, host miRNAs can also act as doublesided coin, where the interplay between host miRNAs and SARS-CoV-2 can promote viral pathogenesis by deregulating the major antiviral immune-signaling pathways (Sarma et al. 2020; Khan et al. 2020), as shown in Fig. 2, which illustrates CoV-2 host-immune escaping mechanism(s), where hostmiRNAs are being sponged by the viral-miRNAs to facilitate viral-directed immune evasion, which includes IFN-gamma,
Fig. 3 SARS-CoV-2 infection outcome regulatory triangle system. The role of miRNAs in SARS-CoV-2 prognosis; host miRNAs, viral-encoded miRNAs, and both mRNA and miRNA targets, contributing to the infection outcome to be either moderate, severe, or mild

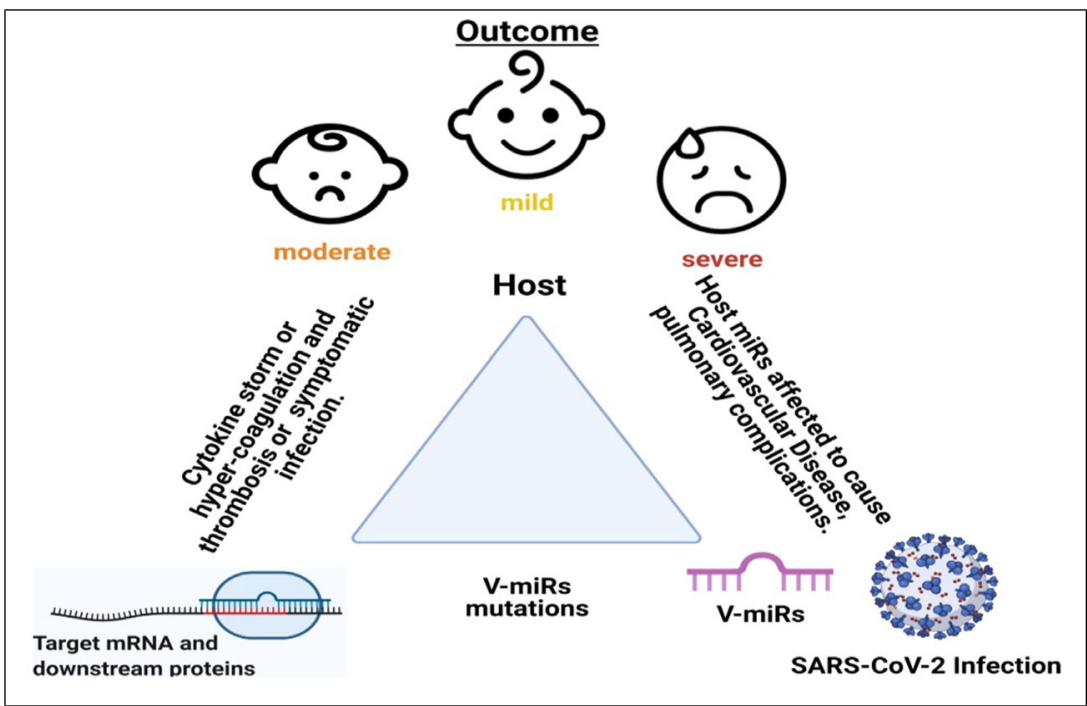


Fig. 4 Epigenetic modulation, namely, gene expression alteration as molecular mechanisms of $\mathrm{CoV}-2$ pathogenesis

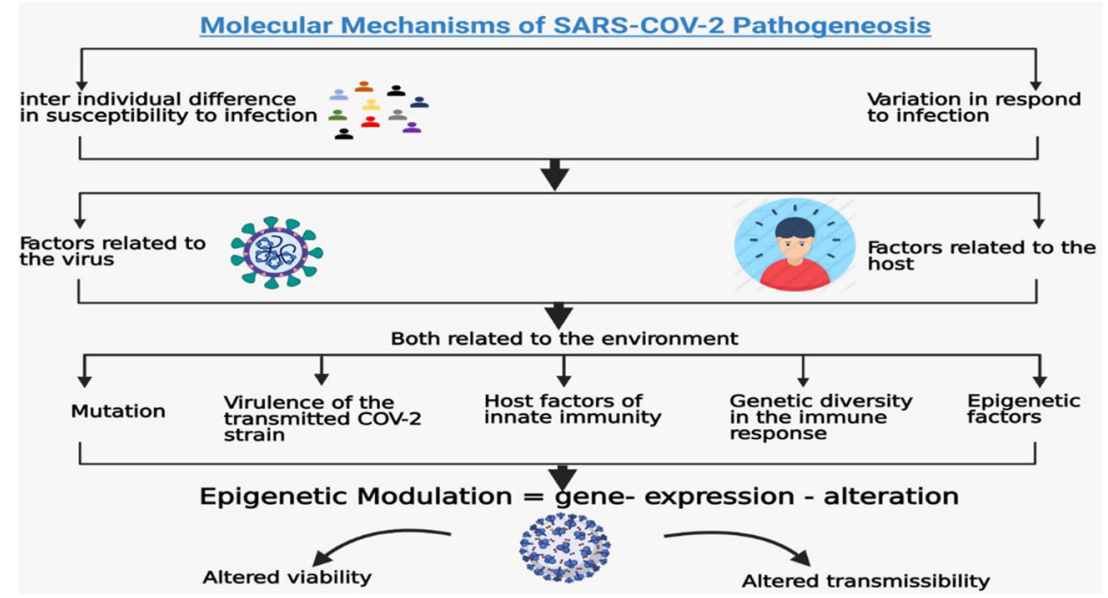

transforming growth factor-beta (TGF-beta), interleukin (IL), insulin-like growth factor-1 (IGF-1), and tumor necrosis factor-related apoptosis-inducing ligand (TRAIL) (Sarma et al. 2020; Khan et al. 2020). During SARS-CoV-2 infection, host-miRNAs may downregulate different toll-like receptors (TLRs) signaling, essential for the host antiviral mechanisms development. Several additional signaling pathways including tumor necrosis factor receptor-associated factor 6 (TRAF6), sphingosine 1-phosphate receptor 1 (S1P1), estrogen receptor, and protease-activated receptor (PAR) are inhibited by viralmiRNAs resulting, unfortunately, in a decline of the hostantiviral defense (Abu-Izneid et al. 2020; Khan et al. 2020; Sardar et al. 2020). Both cellular miRNAs and viral-encoded miRNAs induced post-SARS-CoV-2 infection were found to target cytokine-signaling involved during the immune response, with a net result of an increased viral pathogenesis (Khan et al. 2020) (Fig. 2).

Nucleocapsid protein of the human Betacoronavirus 1 OC43 (HCoV-OC43), which enters its host cell by binding to the N-acetyl-9-O-acetylneuraminic acid receptor, binds to hsa-miR-9-5p, with subsequent activation of the transcription factor nuclear factor-kappa B cell $(\mathrm{NF}-\kappa \mathrm{B})$ and more alteration of the innate immune response (Beidas and Chehadeh 2018).

Additionally, studies revealed the promising possibility of using miRNAs as COVID-19 diagnostic biomarkers as well as to reflect infection severity (Abedi et al. 2020), including hsa-let-7a, hsa-miR101, hsa-miR125a-5p, hsa-miR126, hsamiR222, hsa-miR23b, hsa-miR378, hsa-miR380-5, and hasmiR98 (Abu-Izneid et al. 2020). The host-miRNAs involved in the nuclear machinery can be manipulated to encode specific viral-miRNA-like-RNA fragments to control the virus life cycle together with the host immune response (Mishra et al. 2020).

\section{Viral miRNAs and SARS-CoV-2 miRNAs}

Viral miRNAs are the ugly face of the currently studied miRNAs in relation to COVID-19 infection. Viral miRNAs can regulate the host-gene expression (miRNA targets), cellular proliferation, and stress-related genes. Therefore, SARSCoV-2 can interfere with human innate and adaptive immunity via the viral epigenetic-sensitive machinery (Crimi et al. 2020). SARS-CoV-2-encoded miRNA interactions with the host-miRNA can target autophagy pathways, IFN-1/wingless-related integration site/mechanistic target of rapamycin, previously referred to as the mammalian target of rapamycin (IFN-1/Wnt/mTOR) signaling and $\mathrm{Ca}^{2+}$ signaling pathway (Khan et al. 2020) and, again, activate pro-inflammatory cytokines via an increased NF-KB activity (Identify et al. 2020). Additionally, viral miRNAs 8066, 5197, 3611, 3934-3p, 1307-3p, 3691-3p, and 1468-5p may modulate host-cell response and facilitate SARS-CoV-2 infection (de Sanctis et al. 2020; Identify et al. 2020).

An altered host-miRNA expression may be involved in the CS occurring post-SARS-CoV-2 infection, by triggering the cascade of chemokine signaling through targeting $\mathrm{C}-\mathrm{X}-\mathrm{C}$ chemokine ligand 16 (CXCL16) and the putative enhancer region of arrestin beta- 2 leading to lung inflammation (Abedi et al. 2020). miR-66-3p was also found to target tumor necrosis factor-alpha (TNF-alpha) in the spleen (Abedi et al. 2020). $\mathrm{CS}$, observed in severe infected cases, could be attributed to miR-8066 that activates NF- $\mathrm{BB}-$ mediated TLR-8 expression and, hence, induces more pro-inflammatory cytokine synthesis (de Sanctis et al. 2020).

In addition, SARS-CoV-2 can evade the host's immune surveillance by utilizing its miRNAs to target a myriad of significant functions and pathways involved in the host immune response, such as MAPK signaling, T-cell-mediated immunity, fibroblast growth factor (FGF) receptor binding 
and vascular endothelial growth factor (VEGF) signaling, ErbB signaling (Abedi et al. 2020), and erythroblastic leukemia viral oncogene type I receptor family epidermal growth factor (EGF) receptor (EGFR), suggesting a "CoV-2 host-immune-escaping mechanism(s)" without any symptoms of COVID-19 infection (Fig. 2). SARS-CoV-2 can release its v-miRNAs into the host cells to overturn and neutralize host-cell apoptosis or autophagy, counteracting the defense mechanism employed by the host via apoptosis/autophagy balance to reduce and/or localize the viral spread (Crimi et al. 2020).

Viral miRNA can escape the host-immune cell degradative action, by suppressing certain mRNA de-adenylase transcription complex(es) as the carbon catabolite repressionnegative on TATA-less subunit 4 (CCR4-Not; CNot4), CNot6 ligand, and CNot10 subunits (Abedi et al. 2020).

Moreover, SARS-CoV-2 miRNAs can inhibit the host production of antiviral proteins, increasing the susceptibility of cells to SARS-CoV-2 infection via affecting Janus kinase (JAK) 1 and 2 and signal transducer and activator of transcription (STAT) 3, 4, 5B, and 6 and upregulating the suppressor of cytokine signaling (SOCS) cellular genes. Viral miRNAs can prevent RNA polymerase II attachment to the host gene promoters at the initiation stage or by targeting transcription regulators involved in the transcription machinery (de Sanctis et al. 2020) (Fig. 2).

\section{Role of miRNAs in SARS-CoV-2 prognosis}

Host miRNAs, viral-encoded miRNAs, and both mRNA and miRNA targets, together form a regulatory triangle system (Khan et al. 2020) (Fig. 3), between both the host and virus, contributing to the infection outcome to be either moderate, severe, or mild. The severity of COVID-19 infection in elderly patients, namely mortality, could be explained on the basis of a lower abundance of the host defensive miRNAs.

The upregulation of miRNA 197-5p is implicated in CV complications in SARS-CoV-2 patients (de Sanctis et al. 2020). SARS-CoV-2 miRNAs have been also found to inhibit ribosomal translation of some primary human proteins including olfactory receptor proteins (ORP), hemoglobin, and IFN, resulting in dysosmia, marked disruption of oxygen delivery to vital organs, and generalized hypoxic condition (Khan et al. 2020; Vavougios 2020). Additionally, several host miRNAs, namely miR-320a, miR-3188, miR-3661, miR-217, miR-429, and miR-421, may be involved in the deregulation of different pathways involved in the acute lung injury observed in SARSCoV-2-infected patients (Islam and Khan 2020). Consequently, miRNAs can be the key epigenetic modulator behind the increased post-COVID-19 complications observed in some patients, but not others; therefore, they could be utilized for testing to predict COVID-19 infection severity (Guterres et al. 2020).
Khan et al. observed, by comparing the host miRNA profiles of 67 SARS-CoV-2 isolates from 24 different countries worldwide, several clusters and associated miRNAs. They correlated these clusters with the mortality rates across the globe (Khan et al. 2020), suggesting a link to higher susceptibility to SARS-CoV-2 infection observed in the Europeans.

Moreover, there is a possible link between host miRNAs and severity of the disease as well as treatment outcomes in some populations (Samaddar et al. 2020). For instance, host miRNAs in the Indian population, namely hsa-let-7a, hsamiR101, hsa-miR125a-5p, hsa-miR126, hsa-miR222, hsamiR23b, hsa-miR378, hsa-miR380-5, and hsa-miR98, can potentially target SARS-CoV-2 (Samaddar et al. 2020), where hsa-miR-27b is hypothesized to have a specific defensive role against SARS-CoV-2 in the Indian population (Sardar et al. 2020).

Another study analyzed miRNAs from five genomes of SARS-CoV-2 and identified 22 potential viral miRNAs being linked with 12 human miRNAs (Sarma et al. 2020), based on nucleotide similarity and gene ontology, where the interaction between human miRNAs and the viral genome may be involved in mediating the host pathway(s) which may/may not accelerate the virus pathogenic condition(s) (Gemmati et al. 2020).

\section{Viral genome mutation and v-miRNA mutations}

Mutation rate can greatly affect the SARS-CoV-2 host susceptibility, viral pathogenicity, and the antiviral immune response, which are, therefore, linked to disease severity and mortality rates (Abu-Izneid et al. 2020; Deng et al. 2020). These mutations can lead to either gain or loss of v-miRNA host-cell-binding sites, with subsequent changes in viral replication (Henzinger et al. 2020). For example, mutations in SARS-CoV-2 variant that bind to miR-4701-3p render the virus less prone to miRNA-mediated RNA decay, due to a reduced miR-4701-3p expression in the lung tissues (Mukherjee and Goswami 2020). The loss of miR-197-5p binding site, through viral mutations, results in viral transcript degradation, allowing SARS-CoV-2 to escape from the miRNA-mediated immune defense (Hosseini Rad and McLellan 2020). miRNA-based therapeutic options may serve as either miRNA antagonists and/or miRNA mimics (Henzinger et al. 2020; Abu-Izneid et al. 2020).

\section{Long noncoding RNAs (IncRNAs)}

Understanding the role of lncRNA (having a size of more than 200 nucleotides) in the deregulated cellular environment of SARS-CoV-2 infection is crucial, as it regulates processes involved during viral infection, viral proliferation, and cellular response (Turjya et al. 2020). Host lncRNA metastasisassociated lung adenocarcinoma transcript 1 (MALAT1) and 
nuclear-enriched abundant transcript 1 (NEAT1) in infected SARS-CoV-2 cells could be used as potential biomarkers for monitoring infection progression and measuring disease severity (Henzinger et al. 2020; Vishnubalaji et al. 2020). Moreover, silencing of the MALAT1 1ncRNA might lead to post-CoV-2 infection-CS reduction, where lncRNA acts like a sponge to prevent virally induced miRNAs to attach the host upregulated immune genes (Henzinger et al. 2020).

COVID-19-associated febrile temperatures were shown to induce widespread changes in the transcriptome that would affect the regulation of multiple epigenetic pathway dysregulation as one of the hallmarks of CoV-2 infection, one of which is IncRNA expression, that can lead to SARS-CoV-2 replication inhibition (Herder et al. 2020).

\section{DNA methylation}

The dynamic epigenetic modification, namely DNA methylation, could be useful for pointing out gene regulation, chromosome stability, and establishment of heterochromatin (Table 2) (Schäfer and Baric 2017; Menachery et al. 2018). Moreover, acquired DNA methylation changes may be a potential molecular biomarker in predicting adverse health outcomes (Franzen et al. 2020) and disease severity (Choudhary et al. 2020). DNA methylation signatures depend on the host cell type, gender, and age, which are risk factors associated with an increased risk of COVID-19 infection together with poor prognosis (Crimi et al. 2020) and with severe outcomes (Chlamydas et al. 2020; Franzen et al. 2020; Sang et al. 2020; Yao and Lawrence 2020).

Aging can affect $A C E 2$ gene DNA methylation levels and can mediate age-dependent differences in regard to host response (Franzen et al. 2020; Choudhary et al. 2020). One study indicated that age-associated hypomethylation at the CpG site located near the ACE2 transcription start site in the airway epithelial cells is correlated with an increased expression of ACE2 gene (Franzen et al. 2020), allowing SARSCoV-2 entry to the host cell.

Similarly, epigenetic modulation of TMPRSS2 involves enhanced methylation that reduces the $\mathrm{S}$ protein priming (Henzinger et al. 2020). Moreover, methylation of adenine within the mRNA molecule at position 6 (N6methyladenosine, m6A) alters mRNA stability of both cellular and viral transcripts, affecting their translation efficiency and RNA-protein interaction (Choudhary et al. 2020).

Silent hypoxemia observed in some COVID-19 patients can lead to alteration of DNA methylation patterns (Beacon et al. 2020). Demethylation of IFN-regulated genes, $\mathrm{NF}_{-\mathrm{k}} \mathrm{B}$ and the main cytokine genes, enhances the expression of more pro-inflammatory cytokines and chemokines, thereby increasing CS incidence, with an increased infection severity (El Baba and Herbein 2020). Epigenetic intervention affecting
DNA methylation may be suggested as a primary and/or secondary preventive option.

\section{Histone modifications}

Posttranslational modifications in the histone protein as methylation, acetylation, and phosphorylation can occur leading to alterations in the DNA interactions with nuclear protein, which changes the chromatin architecture and gene activation (Ragia and Manolopoulos 2020). Previous investigations (Table 3) have shown that ACE2 and IL-6 genes are among a class of interferon-stimulated genes (ISGs) that can undergo epigenetic regulation through histone modifications and can be potential biomarkers for SARS-CoV-2 infection (Chlamydas et al. 2020; Sang et al. 2020). Pinto et al. have reported that the histone modification mono-methylation and trimethylation at the 4th lysine residue of the histone $\mathrm{H} 3$ protein (H3K4me1 and $\mathrm{H} 3 \mathrm{~K} 4 \mathrm{me} 3$, respectively); acetylation of the lysine residue at $\mathrm{N}$-terminal position 27 of the histone $\mathrm{H} 3$ protein (H3K27Ac) in the ACE2 gene is associated with an increased ACE2 expression (Pinto et al. 2020). H3K9me2 is involved in DNA methylation and heterochromatin formation. H3K 4me3 regulates TLRs which play an important role in the host's innate immune system (El Baba and Herbein 2020). Histone acetylation (H3K9Ac, H3K36Ac, and H4K5Ac) causes the suppression of the developed IL-8 and TNF-alpha levels in response to COVID-19 infection (El Baba and Herbein 2020). NAD-dependent histone deacetylase sirtuin 1 (silent mating type information regulation 2 homolog1) (SIRT1), which deacetylates transcription factors involved in cellular metabolism regulation, is associated with an increased ACE2 expression (Pinto et al. 2020) and is upregulated in COVID-19 patients' lungs with extreme chronic conditions (El Baba and Herbein 2020).

Acetylation and hypermethylation changes as histone marks as another one of the hallmarks of CoV-2 infection can lead to upregulation of the pro-inflammatory cytokines set (IL-1 $\beta$, IL-6, IL-12, TNF-5-007) and chemokine (C-C motif) ligand (CCL2, 3, 5), CXCL8, CXCL9, and CXCL10 by the effector cells contributing to the fatal CS in severe COVID-19 cases (Ovsyannikova et al. 2020). Repressive histone marks high levels can result in an IL-12 and IL-1 $\beta$ level reduction, contributing to COVID-19 infection severity (Chlamydas et al. 2020).

SARS-CoV-2-infected patients are at higher risk of intravascular coagulation and thromboembolic events (Cattaneo et al. 2020). Neutrophil extracellular trap (NET) is a type of the innate immunity for pathogens entrapment, in which histone $\mathrm{H} 3$ modifications cause neutrophil cell death, platelet aggregation, and scaffold formation (Crimi et al. 2020). This later scaffold consists of DNA and histones, as well as chromatin fibers. NET scaffold may cause multiorgan damage and mortality in severely COVID-19-affected patients 
(McCracken et al. 2020). Multiorgan damage is mediated via autoantibodies formation to severe NET formation (NETosis); a defense mechanism that neutrophils deploy as an alternative to phagocytosis, to constrain the spread of fungi, large bacteria, or viruses.

Wang et al. discovered that G9a, a histone methyltransferase that is overexpressed in COVID-19 patients, demonstrated high viral load and activates specific gene translation inducing an increased inflammatory reaction and T-cell function impairment or lymphopenia, which may contribute to the high mortality rate seen in those patients (Wang et al. 2020). Human identical sequence (HIS)-containing virus fragments can increase H3K27Ac enrichment in their genome corresponding regions and enable more expression of the inflammation-associated genes ( $\mathrm{Li}$ et al. 2020).

\section{Chromatin remodeling (Table 4)}

Chromatin remodeling complex is composed of reversible histone and DNA modifications that controls chromatin composition and role (Schäfer and Baric 2017; Fadason et al. 2020). Euchromatin is more accessible, less tightly packed chromatin, that is linked with active marks like histone acetylation and $\mathrm{H} 3$ methylation at lysine 4. However, the repressed chromatin form, named heterochromatin, is linked with repressive marks like methylation of $\mathrm{H} 3$ at lysine 27 (H3K27me3) and lysine 9 (H3K9me2/3) (Beacon et al. 2020). Poor prognosis observed in elderly COVID-19 patients may be linked to the pre-existing reduction of ACE2 expression, controlled by chromatin structure and ACE2-related host-derived pathways imbalance (Fadason et al. 2020). Giroux et al. analyzed the response of peripheral blood mononuclear cell throughout SARS-CoV-2 infection of patients with different degrees of symptom severity. Giroux group demonstrated chromatin remodeling in certain innate immune populations (CD14+ monocytes) to be associated with divergence in symptom severity and the identified transcription factors, regulatory elements, and downstream pathways. All these would be potential prognostic markers for COVID-19 infection (Giroux et al. 2020).

ISG transcription initiation requires additional chromatin remodelers and transcription factors including ATPdependent chromatin remodeling complex, in addition to inducing histone methylation and acetylation: H3K4me3 and H4Ac (Choudhary et al. 2020). It was found that SARS$\mathrm{CoV}-2$ can induce repression of $A C E 2$ via chromatin remodeling, therefore, altering the regulatory elements within ACE2 gene region that modulates the expression of genes $P I R$ (encodes Pirin), CA5BP1 (a pseudogene of CA5B), and CA5B (encodes mitochondrial carbonic anhydrase) in lung tissues. The gene products of these genes are involved in the $\mathrm{NF}_{\mathrm{K}} \mathrm{B}$ inflammatory responses and de novo pyrimidine synthesis, promoting an intracellular environment suitable for the viral replication (Fadason et al. 2020).

\section{Summary}

Molecular mechanisms of CoV-2 pathogenesis (Fig. 4) points to epigenetic(s); namely, the gene (DNA-methylation), its expression (noncoding RNA; microRNA; or lncRNA); or postexpression alteration $=$ posttranslation (histone modifications; acetylation, de-acetylation, or methylation). Epigenetic modulations involve chromatin structure modulation or posttranscriptional modification by protein-RNA interaction or all together. Epigenetic landscape tends to contribute to variation in the host susceptibility to SARS-CoV-2 infection and to the host post-infection pathological features and severity of symptoms.

\section{Study limitation}

The context of the limitations lay in the limited availability of epigenetic routine markers and the inclusion of articles in English language only. Many observational studies were included due to the scarcity of RCTs, with the notion that observational studies cannot discover causality.

\section{Conclusions}

Epigenetics are molecular biomarkers that can regulate immunity-related gene targets through complex networks of virus-host cell interactions. Epigenetic pathways dysregulation is to be considered as hallmarks of $\mathrm{CoV}-2$ infection. The current SRR has highlighted the crucial role of host and viral epigenetics during $\mathrm{CoV}-2$ pandemic, necessitating the importance of implementing "epigenetic diagnostics" and/or "epigenome nation-wide research." The human epigenetic(s) alteration(s) observed in coronavirus-infected patients are listed and were found to be linked to COVID-19 susceptibility, severity of infection, and/or outcome.

\section{Prospective}

(1) Epigenetic tests for SARS-CoV-2 are warranted to categorize patients into various treatment classes as an essential step for national PM practice. (2) The urge to develop or repurpose epi-drugs to various epigenetic target(s) is the current priority of drug design research in order to control this multi-wave rapidly and constantly mutating pandemic.

Supplementary Information The online version contains supplementary material available at https://doi.org/10.1007/s11356-021-15588-6. 
Abbreviations ACE2, angiotensin-converting enzyme 2; ADAM17, a disintegrin and metalloproteinase domain 17; CA5B, carbonic anhydrase 5b; CCL, chemokine (C-C motif) ligand; CCR4-Not, CNot4, carbon catabolite repression - negative on TATA-less subunit 4; CS, cytokine storm; CV, cardiovascular; CXCL16, C-X-C motif chemokine ligand 16; ErbB, erythroblastic leukemia viral oncogene type I receptor family epidermal growth factor (EGF) receptor (EGFR); FAK, focal adhesion kinase; FGF, fibroblast growth factor; hsa, human microRNA; HCoVOC43, human coronavirus OC43; H3K4me1, mono-methylation at the 4th lysine residue of the histone $\mathrm{H} 3$ protein; $\mathrm{H} 3 \mathrm{~K} 4 \mathrm{me} 3$, trimethylation at the 4th lysine residue of the histone $\mathrm{H} 3$ protein; H3K27Ac, acetylation of the lysine residue at $\mathrm{N}$-terminal position 27 of the histone $\mathrm{H} 3$ protein; HIS, human identical sequences; IFN, interferons; IGF-1, insulin-like growth factor-1; IL-, interleukin-; ISGs, interferon-stimulated genes; JAK, Janus kinase; JARID1B, Jumonji/ARID domain-containing protein 1B; LncRNA, long noncoding RNAs; MALAT1, metastasis-associated lung adenocarcinoma transcript1; MAPK, mitogen-activated protein kinases; miRNAs, microRNAs; mRNAs, messenger RNAs; mTOR, mechanistic target of rapamycin; NEAT1, nuclear-enriched abundant transcript 1; NET, neutrophil extracellular traps; NETosis, NET formation; ncRNAs, nonprotein-coding RNAs; $\mathrm{NF}_{\mathrm{K}} \mathrm{B}$, nuclear factor kappa $\mathrm{B}$; ORP, olfactory receptor proteins; PAR, protease-activated receptor; PDGF, platelet-derived growth factor; PM, precision medicine; PRISMA, preferred reporting items of the systematic review and metaanalysis; p53, phosphoprotein 53; RCT, randomized controlled clinical trial; S, spike; SARS, sever acute respiratory syndrome; SDGs, sustainable development goals; SOCS, suppressor of cytokine signaling; S1P1, sphingosine-1-phosphate receptor1; SIRT1, NAD-dependent histone deacetylase sirtuin 1; Sirtuin1, silent mating type information regulation 2 homolog 1; SRR, systematic rapid review; STAT5B, signal transducer and activator of transcription $5 \mathrm{~B}$; TGF- $\beta 1$, transforming growth factorbeta 1; TLRs, toll-like receptors;; TMPRSS 2, transmembrane protease serine 2; TNF-alpha, tumor necrosis factor-alpha; TRAF6, tumor necrosis factor receptor-associated factor 6; TRAIL, tumor necrosis factor-related apoptosis-inducing ligand; 3'UTR, 3' un-translated region; VEGF, vascular endothelial growth factor; Wnt, wingless-related integration site; vmiRNAs, viral-miRNAs

\section{Acknowledgements Biorender https://biorender.com}

Author contribution SGA, the senior investigator, setting the idea, resolving investigator authors' disagreements, revising Table 1 and PRISMA flowchart, revising the written first manuscript draft, and rewriting and revising till the final draft. AAR, AMB, LAE1, NS, LAE2, NA, and MMM: selection of studies, titles, and abstracts for eligibility; identification of studies meeting the inclusion criteria; rechecking selected studies, figures, and GA drafting; PRISMA flowchart drafting; Table 1 synthesis; writing of the first manuscript draft and rewriting till the final form. NMH, the chief investigator: setting the idea, registering to PROSPERO, resolving investigator authors' disagreements, setting figures and GA drafting, revising figures and PRISMA flowchart drawing, setting and revising Table 1 synthesis, revising the first manuscript draft, and rewriting and revising the final manuscript till submission.

Data availability Not applicable.

\section{Declarations}

Ethics approval Not applicable

Consent to participate Not applicable.

Consent for publication All authors have read the manuscript and agreed to publish.
Conflict of interest The authors declare no competing interests.

\section{References}

Abedi F, Rezaee R, Hayes AW, Nasiripour S, Karimi G (2020) MicroRNAs and SARS-CoV-2 life cycle, pathogenesis, and mutations: biomarkers or therapeutic agents? Cell Cycle 00:1-11. https:// doi.org/10.1080/15384101.2020.1867792

Abu-Izneid T, AlHajri N, Ibrahim AM, Javed MN, Salem KM, Pottoo FH, Kamal MA (2020) Micro-RNAs in the regulation of immune response against SARS CoV-2 and other viral infections. J Adv Res 30:133-145. https://doi.org/10.1016/j.jare.2020.11.013

Beacon TH, Su RCR-CRC, Lakowski TM, Delcuve GP, Davie JR (2020) SARS-CoV-2 multifaceted interaction with the human host. Part II: innate immunity response, immunopathology, and epigenetics. IUBMB Life 72(11):2331-2354. https://doi.org/10.1002/iub.2379

Beidas M, Chehadeh W (2018) Effect of human coronavirus OC43 structural and accessory proteins on the transcriptional activation of antiviral response elements. Intervirology 61(1):30-35. https://doi.org/ $10.1159 / 000490566$

Canatan D (2020) The impact of micrornas (Mirnas) on the genotype of coronaviruses. Acta Biomed 91(2):195-198. https://doi.org/10. 23750/abm.v91i2.9534

Cattaneo M, Bertinato EM, Birocchi S, Brizio C, Malavolta D, Manzoni M, Muscarella G, Orlandi M (2020) Pulmonary embolism or pulmonary thrombosis in COVID-19? Is the recommendation to use high-dose heparin for thromboprophylaxis justified? Thromb Haemost 120(8):1230-1232. https://doi.org/10.1055/s-00401712097

Chlamydas S, Papavassiliou AG, Piperi C (2020) Epigenetic mechanisms regulating COVID-19 infection. Epigenetics 16:263-270. https:// doi.org/10.1080/15592294.2020.1796896

Choudhary S, Sreenivasulu K, Mitra P, Misra S, Sharma P (2020) Role of genetic variants and gene expression in the susceptibility and severity of COVID-19. Ann Lab Med 41(2):129-138. https://doi.org/10. 3343/alm.2021.41.2.129

Crimi E, Benincasa G, Figueroa-Marrero N, Galdiero M, Napoli C (2020) Epigenetic susceptibility to severe respiratory viral infections and its therapeutic implications: a narrative review. Br J Anaesth 125(6): 1002-1017. https://doi.org/10.1016/j.bja.2020.06.060

Daneshkhah A, Agrawal V, Eshein A, Subramanian H, Roy HK, Backman V (2020) The possible role of vitamin D in suppressing cytokine storm and associated mortality in COVID-19 patients. Aging Clin Exp Res 32(10): 2141-2158. https://doi.org/ 10.1007/s40520-020-01677-y

de Sanctis JB, García A, Garmendia J, Moreno D, Hajduch M, Radzioch $D$ (2020) Importance of miRNA in SARS-CoV2 infection. Gac Med Caracas 128(1S):S17-S22. https://doi.org/10.47307/GMC.2020. 128.s 1.3

Deng Q, ur Rasool R, Russell RM, Natesan R, Asangani IA (2021) Targeting androgen regulation of TMPRSS2 and ACE2 as a therapeutic strategy to combat COVID-19. iScience 24(3): 102254. https://doi.org/10.1016/j.isci.2021.102254.

El Baba R, Herbein G (2020) Management of epigenomic networks entailed in coronavirus infections and COVID-19. Clin Epigenetics 12(1):1-12. https://doi.org/10.1186/s13148-02000912-7

Fadason T, Gokuladhas S, Golovina E, Ho D, Farrow S, Nyaga D, Pan H, Karnani N, Wong C, Cooper A, Schierding W, O'Sullivan J (2020) A transcription regulatory network within the ACE2 locus may promote a pro-viral environment for SARS-CoV-2 by modulating expression of host factors. bioRxiv https://doi.org/10.1101/2020.04. 14.042002 
Franzen J, Nüchtern S, Tharmapalan V, Vieri M, Nikolic M, Han Y, Balfanz P, Marx N, Dreher M, Bruemmendorf TH, Dahl E, Beier F, Wagner W (2020) Epigenetic clocks are not accelerated in COVID-19 patients. medRxiv https://doi.org/10.1101/2020.11.13. 20229781

Gemmati D, Bramanti B, Serino ML, Secchiero P, Zauli G, Tisato V (2020) COVID-19 and individual genetic susceptibility/receptivity: Role of ACE1/ACE2 genes, immunity, inflammation and coagulation. might the double $\mathrm{x}$-chromosome in females be protective against SARS-COV-2 compared to the single $\mathrm{x}$-chromosome in males? Int J Mol Sci 21(10):3474. https://doi.org/10.3390/ ijms21103474.

Giroux NS, Ding S, McClain MT, Burke TW, Petzold E, Chung HA, Palomino GR, Wang E, Xi R, Bose S, Rotstein T, Nicholson BP, Chen T, Henao R, Sempowski GD, Denny TN, Ko ER, Ginsburg GS, Kraft BD, Tsalik EL, Woods CW, Shen X (2020) Chromatin remodeling in peripheral blood cells reflects COVID-19 symptom severity. bioRxiv. https://doi.org/10.1101/2020.12.04.412155.

Guterres A, de Azeredo Lima CH, Miranda RL, Gadelha MR (2020) What is the potential function of microRNAs as biomarkers and therapeutic targets in COVID-19? In: Infection, Genetics and Evolution, vol 85. Elsevier B.V., Amsterdam, p 104417. https:// doi.org/10.1016/j.meegid.2020.104417

Henzinger H, Barth DA, Klec C, Pichler M (2020) Non-coding RNAs and SARS-related coronaviruses. Viruses 1;12(12):1374. https:// doi.org/10.3390/v12121374.

Herder V, Dee K, Wojtus JK, Goldfarb D, Rozario C, Gu Q, Jarrett RF, Epifano I, Stevenson A, McFarlane S, Stewart ME, Szemiel AM, Pinto RM, Garriga AM, Graham SV, Murcia PR, Boutell C (2020) Elevated temperature inhibits SARS-CoV-2 replication in respiratory epithelium independently of the induction of IFN-mediated innate immune defences. bioRxiv https://doi.org/10.1101/2020.12.04. 411389. Accessed January 2021

Hosseini Rad Sm A, McLellan, AD (2020) Implications of SARS-CoV-2 mutations for genomic RNA structure and host microRNA targeting. Int J Mol Sci 21(13):4807. https://doi.org/10.3390/ ijms 21134807

Identify D, Arisan ED, Dart A, Grant GH, Arisan S, Cuhadaroglu S, Lange S, Uysal-onganer P (2020) The Prediction of miRNAs in SARS-CoV-2 Genomes: hsa-miR Databases Identify 7 Key miRs Linked to Host Responses and Virus Pathogenicity-Related KEGG Pathways Significant for Comorbidities. Viruses 12(6):614. https:// doi.org/10.3390/v12060614.

Islam ABMM, Khan MAAK (2020) Lung transcriptome of a COVID-19 patient and systems biology predictions suggest impaired surfactant production which may be druggable by surfactant therapy. Sci Rep 10:19395. https://doi.org/10.1038/s41598-020-76404-8

Khan MA, Islam ABMM (2021) SARS-CoV-2 proteins exploit host's genetic and epigenetic mediators for the annexation of key host signaling pathways that confers its immune evasion and disease pathophysiology. Front Mol Biosci 7:598583. https://doi.org/10. 3389/fmolb.2020.598583

Khan MA, Sany MRU, Islam MS, Islam ABMMK (2020) Epigenetic Regulator miRNA Pattern Differences Among SARS-CoV, SARS-CoV-2, and SARS-CoV-2 World-Wide Isolates Delineated the Mystery Behind the Epic Pathogenicity and Distinct Clinical Characteristics of Pandemic COVID-19. Front Genet 11:765. https://doi.org/10.3389/fgene.2020.00765

Li W, Yang S, Xu P, Zhang D, Tong Y, Chen L, Jia B, Li A, Ru D, Zhang B, Liu M, Lian C, Chen C, Fu W, Yuan S, Ren X, Liang Y, Yang Z, $\mathrm{Li}$ W et al (2020) Human identical sequences of SARS-CoV-2 promote clinical progression of COVID-19 by upregulating hyaluronan via NamiRNA-enhancer network. bioRxiv https://doi.org/10.1101/ 2020.11.04.361576

Liberati A, Altman DG, Tetzlaff J, Mulrow C, Gøtzsche PC, Ioannidis JPA, Clarke M, Devereaux PJ, Kleijnen J, Moher D (2009) The
PRISMA statement for reporting systematic reviews and metaanalyses of studies that evaluate health care interventions: explanation and elaboration. In: Annals of Internal Medicine (vol 151, issue 4). American College of Physicians, Philadelphia. https://doi.org/10. 7326/0003-4819-151-4-200908180-00136

Liu W, Tao ZW, Wang L, Yuan ML, Liu K, Zhou L, Wei S, Deng Y, Liu J, Liu HG, Yang M, Hu Y (2020) Analysis of factors associated with disease outcomes in hospitalized patients with 2019 novel coronavirus disease. Chin Med J 133(9):1032-1038. https://doi.org/10. 1097/CM9.0000000000000775

McCracken I, Saginc G, He L, Huseynov A, Daniels A, Fletcher S, Peghaire C, Kalna V, Andaloussi-Mäe M, Muhl L, Craig NM, Griffiths SJ, Haas JG, Tait-Burkard C, Lendahl U, Birdsey GM, Betsholtz C, Noseda M, Baker A, Randi AM (2021) Lack of evidence of ACE2 expression and replicative infection by SARS-CoV2 in human endothelial cells. Circulation 143:865-868. https://doi. org/10.1161/circulationaha.120.052824

Menachery VD, Schäfer A, Burnum-Johnson KE, Mitchell HD, Eisfeld AJ, Walters KB, Nicora CD, Purvine SO, Casey CP, Monroe ME, Weitz KK, Stratton KG, Webb-Robertson BJM, Gralinski LE, Metz TO, Smith RD, Waters KM, Sims AC, Kawaoka Y, Baric RS (2018) MERS-CoV and H5N1 influenza virus antagonize antigen presentation by altering the epigenetic landscape. Proc Natl Acad Sci U S A 115(5):E1012-E1021. https://doi.org/10.1073/pnas.1706928115

Meng T, Cao H, Zhang H, Kang Z, Xu D, Gong H, Wang J, Li Z, Cui X, Xu H, Wei H, Pan X, Zhu R, Xiao J, Zhou W, Cheng L, Liu J (2020) The transmembrane serine protease inhibitors are potential antiviral drugs for 2019-nCoV targeting the insertion sequence-induced viral infectivity. bioRxiv https://doi.org/10.1101/2020.02.08.926006

Mishra R, Kumar A, Ingle H, Kumar H (2020) The interplay between viral-derived miRNAs and host immunity during infection. Front Immunol 10:3079). Frontiers Media S.A. https://doi.org/10.3389/ fimmu.2019.03079

Mukherjee M, Goswami S (2020) Global cataloguing of variations in untranslated regions of viral genome and prediction of key host RNA binding proteinmicroRNA interactions modulating genome stability in SARS-CoV-2. PLoS One 15(8 August):e0237559. https://doi.org/10.1371/journal.pone.0237559

Ovsyannikova IG, Haralambieva IH, Crooke SN, Poland GA, Kennedy RB (2020) The role of host genetics in the immune response to SARS-CoV-2 and COVID-19 susceptibility and severity. Immunol Rev 296(1):205-219. https://doi.org/10.1111/imr.12897

Pinto BGG, Oliveira AER, Singh Y, Jimenez L, Gonçalves ANA, Ogava RLT, Creighton R, Peron JPS, Nakaya HI (2020) ACE2 expression is increased in the lungs of patients with comorbidities associated with severe COVID-19. J Infect Dis 222(4):556-563. https://doi. org/10.1093/infdis/jiaa332

Pontecorvi G, Bellenghi M, Ortona E, Carè A (2020) microRNAs as new possible actors in gender disparities of Covid-19 pandemic. Acta Physiol 230(1):e13538. https://doi.org/10.1111/apha.13538

Pradhan UK, Anand P, Sharma NK, Kumar P, Kumar A, Pandey R, Padwad Y, Shankar R (2020) Various RNA-binding proteins and their conditional networks explain miRNA biogenesis and help to reveal the potential SARS-CoV-2 host miRNAome system. bioRxiv. https://doi.org/10.1101/2020.06.18.156851

Ragia G, Manolopoulos VG (2020) Assessing COVID-19 susceptibility through analysis of the genetic and epigenetic diversity of ACE2mediated SARS-CoV-2 entry. Pharmacogenomics 21(18):13111329. https://doi.org/10.2217/pgs-2020-0092

Samaddar A, Gadepalli R, Nag VL, Misra S (2020) The enigma of Low COVID-19 fatality rate in India. Front Genet 11:854. https://doi.org/ 10.3389/fgene.2020.00854

Sang ER, Tian Y, Miller LC, Sang Y (2021) Epigenetic evolution of ACE2 and IL-6 genes as Non-canonical interferon-stimulated genes correlate to COVID-19 susceptibility in vertebrates. Genes (Basel) 25;12(2):154. https://doi.org/10.3390/genes12020154 
Sardar R, Satish D, Gupta D (2020) Identification of novel SARS-CoV-2 drug targets by host microRNAs and transcription factors coregulatory interaction network analysis. Front Genet 11:571274. https://doi.org/10.3389/fgene.2020.571274

Sarma A, Phukan H, Halder N, Madanan MG (2020) An in-silico approach to study the possible interactions of miRNA between human and SARS-CoV2. Comput Biol Chem 88:107352. https://doi.org/ 10.1016/j.compbiolchem.2020.107352

Schäfer A, Baric RS (2017) Epigenetic landscape during coronavirus infection. Pathogens 16(1):8. https://doi.org/10.3390/ pathogens6010008

Shang J, Wan Y, Luo C, Ye G, Geng Q, Auerbach A, Li F (2020) Cell entry mechanisms of SARS-CoV-2. Proc Natl Acad Sci U S A 117(21):11727-11734. https://doi.org/10.1073/pnas.2003138117

Srivastava R, Daulatabad SV, Srivastava M, Janga SC (2020) Role of SARS-CoV-2 in altering the rna-binding protein and miRNAdirected post-transcriptional regulatory networks in humans. Int J Mol Sci 21(19):1-18. https://doi.org/10.3390/ijms21197090

Turjya RR, Khan MAAKMA-A-KMAAKMA-A-KMAAK, Mir Md Khademul Islam AB, Islam ABMM, Mir Md Khademul Islam AB (2020) Perversely expressed long noncoding RNAs can alter host response and viral proliferation in SARS-CoV-2 infection. Futur Virol 15(9):577-593. https://doi.org/10.2217/fvl-2020-0188

Vavougios GD (2020) A data-driven hypothesis on the epigenetic dysregulation of host metabolism by SARS coronaviral infection: potential implications for the SARS-CoV-2 modus operandi. Med Hypotheses 140:109759. https://doi.org/10.1016/j.mehy.2020. 109759
Vishnubalaji R, Shaath H, Alajez NM (2020) Protein coding and long noncoding RNA (lncRNA) transcriptional landscape in SARSCoV-2 infected bronchial epithelial cells highlight a role for interferon and inflammatory response. Genes 11(7):1-19. https://doi.org/ $10.3390 /$ genes 11070760

Wang L, Muneer A, Xie L, Zhang F, Wu B, Mei L, Lenarcic EM, Feng EH, Wan YY, Moorman NJ, Song H, Jin J, Chen X, Song J, Xiong Y, Yu X, Wang C, Gheorghe C, Torralba K et al (2020) Novel genespecific translation mechanism of dysregulated, chronic inflammation reveals promising, multifaceted COVID-19 therapeutics. Preprint. https://doi.org/10.1101/2020.11.14.382416

Yao Y, Lawrence DA (2021) Susceptibility to COVID-19 in populations with health disparities: Posited involvement of mitochondrial disorder, socioeconomic stress, and pollutants. J Biochem Mol Toxicol. 35:e22626. https://doi.org/10.1002/jbt.22626

Zarubin A, Stepanov V, Markov A, Kolesnikov N, Marusin A, Khitrinskaya I, Swarovskaya M, Litvinov S, Ekomasova N, Dzhaubermezov M, Maksimova N, Sukhomyasova A, Shtygasheva O, Khusnutdinova E, Radzhabov M, Kharkov V, Radjabov M, Kharkov V, Radzhabov M, Kharkov V (2020) Structural variability, expression profile, and pharmacogenetic properties of TMPRSS2 gene as a potential target for COVID-19 therapy. Genes 12(1):19. https://doi.org/10.3390/genes12010019

Publisher's note Springer Nature remains neutral with regard to jurisdictional claims in published maps and institutional affiliations. 